\title{
Clinical Studies on Ear Infections, Microbiological Evaluation and Therapeutic Management in Canines
}

\author{
J. J. Parmar*, Neha Rao, A. I. Shah, D. B. Sadhu, B. B. Bhanderi and D. M. Patel \\ Veterinary Clinical Complex, College of Veterinary Science and Animal Husbandry, \\ Anand Agricultural University, Anand-188001 India \\ *Corresponding author
}

A B S T R A C T

\begin{tabular}{|l|}
\hline Ke y w o r d s \\
$\begin{array}{l}\text { Otitis externa, } \\
\text { Microbiological } \\
\text { evaluation, } \\
\text { Therapeutics } \\
\text { management }\end{array}$ \\
\hline Article Info \\
\hline $\begin{array}{l}\text { Accepted: } \\
\text { 15 December 2019 } \\
\text { Available Online: } \\
\text { 20 January 2020 }\end{array}$ \\
\hline \hline
\end{tabular}

A total 116 dogs were presented with various affections of the ear, among them $67(57.76 \%)$ cases were having the symptoms of otitis. The higher incidence was found in the age groups of $1-5$ year $(44.77 \%, \mathrm{n}=30)$ followed other age groups. The breed wise incidence of was found to be highest in the Labrador $(35.82 \%, \mathrm{n}=24)$ followed by other breeds. 35 cases had bilateral (52.23\%), 21 dogs had only right side ear (31.34\%) involvement and 11 dogs had left side ear (16.41\%) infection. Out of total 67 cases 58.20 percent $(n=39)$ cases were male and $41.80 \%$ percent $(n=28)$ cases were female. 102 pus samples were collected aseptically for microbiological evaluation and antibiotics sensitivity test revealed 251 isolates from eight bacterial species. The bacterial isolates had different sensitivity pattern. Staphylococcus Spp. was found to be most dominant isolate and found highly sensitive to Cefotaxim and Ceftriaxone. The antibiotics sensitivity testing revealed Gentamycin $(17.93 \%, \mathrm{n}=45)$ to be highly sensitive drug followed by other antibiotics. All the dogs were recovered well without reoccurrence during period of study.

\section{Introduction}

Otitis externa is non-life threatening acute or chronic inflammation of external ear in dogs and but frustrating for patients and owners (Muruganet al.,2016), as well as diagnostic and therapeutic point of view for practicing
Veterinarians (Lakshmi and Tirumala, 2013). Otitis externa in dogs is commonly caused by multiple microbial agents and about $20 \%$ of dog population affected by these disease (Senthelet al., 2010). Still, there is no published data regarding otitis in dogs along with its antimicrobial sensitivity patterns of 
associated bacteria and its management in Gujarat state. So this paper aims to present the various bacterial isolates responsible for otitis lead to severe pain to the dogs and their antibiotic sensitivity pattern for the management and treatment.

\section{Materials and Methods}

The dogs presented to the Veterinary Clinical Complex, Veterinary College, Anand with the complaint of tilting of head, shaking of ears, pawing of ears, abnormal ear discharge with or without foul smell, dropping of affected ears were included in the study. All the dogs were subjected to detailed history, clinical examinations, microbiological evaluation and antibiotics sensitivity testing for therapeutic management.

\section{Results and Discussion}

A total 116 dogs were presented with different conditions of the ear. Among them 67 $(57.76 \%)$ cases were having the symptoms of otitis like tilting of head, abnormal discharge and infection in ears. The dogs were evaluated after thorough clinical examination and the ear swabs were taken aseptically. Most of the cases had history of bathing before seven to twelve days. In some cases there was history of long term medicinal management which did not responded to routine antibiotics therapy and in some cases reoccurrence of ear infection was observed.

Initially all dogs were treated with tropical ear cleansing agent to flush out the pus and debris along with antibiotics according to antibiotic sensitivity test either topical or in combination with parenteral administration. Owners were advised to routine ear cleaning and plugging of ears while bathing of dogs to prevent the chances of moisture retention and risk of infection. All the dogs were recovered well without reoccurrence during period of study.
The higher incidence of otitis externa was found in the age groups of 1-5 year $(44.77 \%$, $\mathrm{n}=30)$, followed by $5-10$ year $(29.65 \%, \mathrm{n}=20)$, $10-15$ year $(13.43 \%, \mathrm{n}=9)$, below one year age group $(10.44 \%, \mathrm{n}=7)$ and above 15 years age $(1.49 \%, \mathrm{n}=1)$ (Fig 1$)$.

The breed wise incidence of otitis was also studied and it was found to be highest in the Labrador $(35.82 \%, \mathrm{n}=24)$ followed by German Shepherd and Pomeranian (16.41\%, $\mathrm{n}=11$, each), Pug $(11.94 \%, \mathrm{n}=8)$ followed by NonDescript (4.47\%, n=3), Doberman, Golden Retriever and Saint Bernard (2.98\%, $\mathrm{n}=2$, each), and Rottweiler, Cocker Spaniel, Dachshund and Beagle (1.49\%, $\mathrm{n}=1$, each) (Fig 2). Out of 67 cases 35 cases had bilateral (52.23\%), 21 dogs had only right side ear $(31.34 \%)$ involvement and $11 \mathrm{dogs}$ had left side ear $(16.41 \%)$ infection. Out of total 67 cases 58.20 percent $(n=39)$ cases were male and $41.80 \%$ percent $(n=28)$ cases were female.

Senthil Kumar et al. (2010) reported otitis externa in dogs having age of three year old but both sexes equally affected whereas Suneja et al. (2012) reported higher incidence of otitis in dogs aged from 2-7 years and male dogs were highly affected than female. Manju et al. (2018) reported otitis externa was higher in old age and male dogs. In contrary to the findings of the present study they found higher incidence of otitis externa in German shepherd followed by other breeds of dogs. Bhojne et al. (2015) reported symptoms similar to findings of present study in dogs having otitis external.

Among 67 affected dogs 102 pus samples were collected aseptically from either single or both ears and subjected to microbiological evaluation by bacterial culture and antibiotics sensitivity testing (Table 1) which revealed 251 isolates from eight bacterial species viz. Staphylococcus Spp. $\quad(56.57 \%, \quad \mathrm{n}=142)$ followed by Streptococcus Spp. (17.13\%, 
$\mathrm{n}=43)$, Gram Negative Rods (11.15\%, $\mathrm{n}=28)$, Escherichia Coli $(5.71 \%, \quad \mathrm{n}=13)$, Corynebactarium Spp.(4.78\%, $\mathrm{n}=12)$, Pseudomonas Spp.(2.39\%, $\mathrm{n}=6)$, Klebsilla Spp. $(1.59 \%, \mathrm{n}=4)$ andGram Positive Rods (1.19\%, $\mathrm{n}=3$ ) having single and mixed infection of two or multiple organisms.

The antibiotics sensitivity testing revealed Gentamycin (17.93\%, $\mathrm{n}=45)$ to be highly sensitive drug followed by Cefotaxim $(17.53 \%, \mathrm{n}=44)$, Ceftriaxone $(15.53 \%, \mathrm{n}=39)$, Amoxicillin Clavulanic acid (11.15\%, $\mathrm{n}=28)$, Enrofloxacin (10.75\%, $\mathrm{n}=27)$, Ampicillin and Tetracycline $(8.36 \%, \mathrm{n}=21$, each), Amikacin (7.97\%, $\mathrm{n}=20)$, Chloramphenicol $(1.59 \%$, $\mathrm{n}=4)$ and Streptomycin $(0.79 \%, \mathrm{n}=2)$.

Lakshmi and Tirumala (2013) and Lodh et al. (2014) reported the more presence of Staphylococcus, Streptococcus, Pseudomonas, Corynebacterium with variable antibiotics sensitivity patterns from the samples of dogs affected with otitis externa than the findings of the present study. In the present study, it was also observed that different isolates had different antibiotic sensitive patterns. Staphylococcus spp. was found sensitive to Cefotaximand Ceftriaxone (16.90\%, $\mathrm{n}=24$, each) followed by Gentamycin (14.79\%, $\mathrm{n}=21)$, Amoxicillin Clavulanic acid $(11.97 \%$, $\mathrm{n}=17), \quad$ Ampicillin $(10.56 \%, \quad \mathrm{n}=15)$, Tetracycline $(9.86 \%, n=14)$, Enrofloxacin (8.45\%, $\mathrm{n}=12)$, Amikacin (7.04\%, $\mathrm{n}=10$ ), Chloramphenicol $(2.11 \%, \quad \mathrm{n}=3) \quad$ and Streptomycin (1.40\%, $\mathrm{n}=2)$. Streptococcus spp. was found sensitive to Gentamycin (27.90\%, $\mathrm{n}=12$ ), Cefotaxim (16.28\%, $\mathrm{n}=7$ ), Ceftriaxone, Enrofloxacin and Amikacin (11.62\%, $\mathrm{n}=5$, each), Amoxicillin Clavulanic acid $(9.30 \%, \mathrm{n}=4)$, Ampicillin $(6.97 \%, \mathrm{n}=3)$ and Tetracycline $(4.65 \%, \quad n=2)$. Gram Negative Rods found sensitive to Cefotaxim $(25 \%, \mathrm{n}=7)$ followed by Ceftriaxone and Enrofloxacin (21.43\%, $\mathrm{n}=6)$, Gentamycin and Amoxicillin Clavulanic acid $(14.28 \%, \mathrm{n}=4)$, and Tetracycline $(3.57 \%, \mathrm{n}=1)$. Escherichia Coli was found to be sensitive toGentamycin $(30.77 \%, \mathrm{n}=4)$ followed by Cefotaxim and Tetracycline $(15.38 \%, \quad \mathrm{n}=2, \quad$ each), Ceftriaxone, Amoxicillin Clavulanic acid, Enrofloxacin, Ampicillin (7.69\%, $\mathrm{n}=1$, each), and Amikacin $(6.66 \%, \mathrm{n}=1)$. Corynebactarium spp. revealed sensitive to Cefotaxim, Ceftriaxone, Ampicillin, and Tetracycline (16.66\%, $\mathrm{n}=2$, each), followed by Gentamycin, Ceftriaxone, Enrofloxacin and Amikacin $(8.33 \%, \mathrm{n}=1$, each). Pseudomonas Spp.revealed highly sensitive to Amikacin $(33.33 \%, \mathrm{n}=2)$ followed by Gentamycin, Cefotaxim, Ceftriaxone and Enrofloxacin $(16.66 \%, \mathrm{n}=1$, each). Klebsilla spp. sensitive to Gentamycin, Enrofloxacin, Amikacin and Chloramphenicol (25\%, $\mathrm{n}=1$, each). Gram Negative Rods were found sensitive to Gentamycin, Cefotaxim, and Ceftriaxone (33.33\%, $\mathrm{n}=1$, each).

Murugan et al. (2016) also reported the Staphylococcus was the major bacterial isolate which was found highly sensitive to Amoxicillin Clavulanic acid where as in the present study it was found to be highly sensitive to Gentamycin followed by other antibiotics. Degiet al. (2010) reported the Pseudomaonas was high sensitive to Gentamycin. In this study different isolates had different antibiotic sensitivity pattern which were more or less similar to findings of other reports.

From the present study as a conclusion, The most common cause of otitis was bathing without ear plugging and the commonest isolates was Staphylococcus spp. responsible for ear infection which was highly sensitive to Cefotaxim and Ceftriaxone. Other organisms were also isolated from the pus samples of ear infection but their frequency is less along with different antibiotic sensitivity pattern. 
Table.1 Antibiotics Sensitivity Pattern of different isolates to antibiotics

\begin{tabular}{|c|c|c|c|c|c|c|c|c|c|}
\hline Isolates & 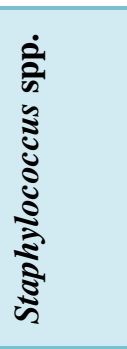 & 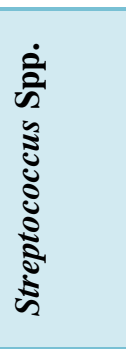 & 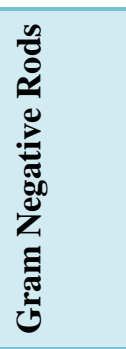 & 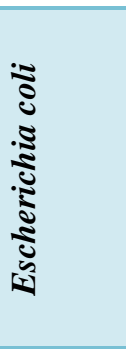 & 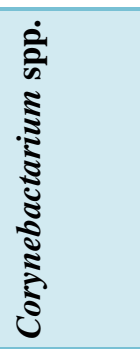 & 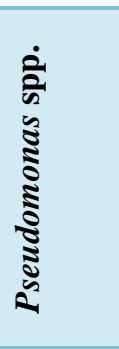 & 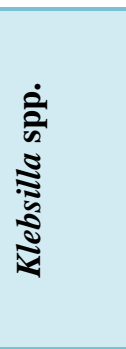 & 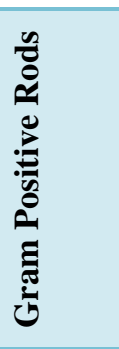 & है \\
\hline Gentamycin & $\begin{array}{c}14.79 \% \\
(21)\end{array}$ & $\begin{array}{l}27.90 \% \\
(12)\end{array}$ & $\begin{array}{l}14.28 \% \\
\text { (4) }\end{array}$ & $\begin{array}{l}30.77 \% \\
\text { (4) }\end{array}$ & $\begin{array}{c}8.33 \% \\
\text { (1) }\end{array}$ & $\begin{array}{l}16.66 \% \\
\text { (1) }\end{array}$ & $\begin{array}{l}25.00 \% \\
\text { (1) }\end{array}$ & $\begin{array}{l}33.33 \% \\
\text { (1) }\end{array}$ & $\begin{array}{c}17.93 \% \\
(45)\end{array}$ \\
\hline Cefotaxim & $\begin{array}{c}16.90 \% \\
(24)\end{array}$ & $\begin{array}{l}16.28 \% \\
(7)\end{array}$ & $\begin{array}{l}25.00 \% \\
(7)\end{array}$ & $\begin{array}{l}15.38 \% \\
(2)\end{array}$ & $\begin{array}{l}16.66 \% \\
(2)\end{array}$ & $\begin{array}{l}16.66 \% \\
\text { (1) }\end{array}$ & - & $\begin{array}{l}33.33 \% \\
\text { (1) }\end{array}$ & $\begin{array}{c}17.53 \% \\
(44)\end{array}$ \\
\hline Ceftriaxone & $\begin{array}{c}16.90 \% \\
(24)\end{array}$ & $\begin{array}{c}11.62 \% \\
(5)\end{array}$ & $\begin{array}{c}21.43 \% \\
\text { (6) }\end{array}$ & $\begin{array}{c}7.69 \% \\
\text { (1) }\end{array}$ & $\begin{array}{l}8.33 \% \\
\text { (1) }\end{array}$ & $\begin{array}{c}16.66 \% \\
\text { (1) }\end{array}$ & - & $\begin{array}{c}33.33 \% \\
\text { (1) }\end{array}$ & $\begin{array}{c}15.53 \% \\
(39)\end{array}$ \\
\hline $\begin{array}{l}\text { Amoxicillin } \\
\text { Clavulanic acid }\end{array}$ & $\begin{array}{l}11.97 \% \\
(17)\end{array}$ & $\begin{array}{l}9.30 \% \\
(4)\end{array}$ & $\begin{array}{l}14.28 \% \\
\text { (4) }\end{array}$ & $\begin{array}{l}7.69 \% \\
(1)\end{array}$ & $\begin{array}{l}16.66 \% \\
\text { (2) }\end{array}$ & - & - & - & $\begin{array}{l}11.15 \% \\
(28)\end{array}$ \\
\hline Enrofloxacin & $\begin{array}{c}8.45 \% \\
(12)\end{array}$ & $\begin{array}{c}11.62 \% \\
(5)\end{array}$ & $\begin{array}{c}21.43 \% \\
(6)\end{array}$ & $\begin{array}{c}7.69 \% \\
\text { (1) }\end{array}$ & $\begin{array}{c}8.33 \% \\
\text { (1) }\end{array}$ & $\begin{array}{c}16.66 \% \\
\text { (1) }\end{array}$ & $\begin{array}{c}25.00 \% \\
\text { (1) }\end{array}$ & - & $\begin{array}{c}10.75 \% \\
(27)\end{array}$ \\
\hline Ampicillin & $\begin{array}{c}10.56 \% \\
(15)\end{array}$ & $\begin{array}{c}6.97 \% \\
(3)\end{array}$ & - & $\begin{array}{c}7.69 \% \\
(1)\end{array}$ & $\begin{array}{c}16.66 \% \\
\text { (2) }\end{array}$ & - & - & - & $\begin{array}{c}8.36 \% \\
(21)\end{array}$ \\
\hline Tetracycline & $\begin{array}{c}9.86 \% \\
(14)\end{array}$ & $\begin{array}{c}4.65 \% \\
(2)\end{array}$ & $\begin{array}{c}3.57 \% \\
\text { (1) }\end{array}$ & $\begin{array}{c}15.38 \% \\
\text { (2) }\end{array}$ & $\begin{array}{c}16.66 \% \\
\text { (2) }\end{array}$ & - & - & - & $\begin{array}{c}8.36 \% \\
(21)\end{array}$ \\
\hline Amikacin & $\begin{array}{c}7.04 \% \\
(10)\end{array}$ & $\begin{array}{c}11.62 \% \\
(5)\end{array}$ & - & $\begin{array}{c}7.69 \% \\
\text { (1) }\end{array}$ & $\begin{array}{c}8.33 \% \\
(1)\end{array}$ & $\begin{array}{c}33.33 \% \\
\text { (2) }\end{array}$ & $\begin{array}{c}25.00 \% \\
\text { (1) }\end{array}$ & - & $\begin{array}{c}7.97 \% \\
(20)\end{array}$ \\
\hline Streptomycin & $\begin{array}{l}1.40 \% \\
\text { (2) }\end{array}$ & - & - & - & - & - & - & - & $\begin{array}{c}1.59 \% \\
(4)\end{array}$ \\
\hline Chloramphenicol & $\begin{array}{l}2.11 \% \\
\text { (3) }\end{array}$ & - & - & - & - & - & $\begin{array}{c}25.00 \% \\
\text { (1) }\end{array}$ & - & $\begin{array}{c}0.79 \% \\
\text { (2) }\end{array}$ \\
\hline Total & $\begin{array}{c}56.57 \% \\
(142)\end{array}$ & $\begin{array}{c}17.13 \% \\
(43)\end{array}$ & $\begin{array}{c}11.15 \% \\
(28)\end{array}$ & $\begin{array}{c}5.17 \% \\
(13)\end{array}$ & $\begin{array}{c}4.78 \% \\
(12)\end{array}$ & $\begin{array}{c}2.39 \% \\
(6)\end{array}$ & $\begin{array}{c}1.59 \% \\
(4)\end{array}$ & $\begin{array}{c}1.19 \% \\
\text { (3) }\end{array}$ & 251 \\
\hline
\end{tabular}

Figures in the parenthesis indicate number of animals.

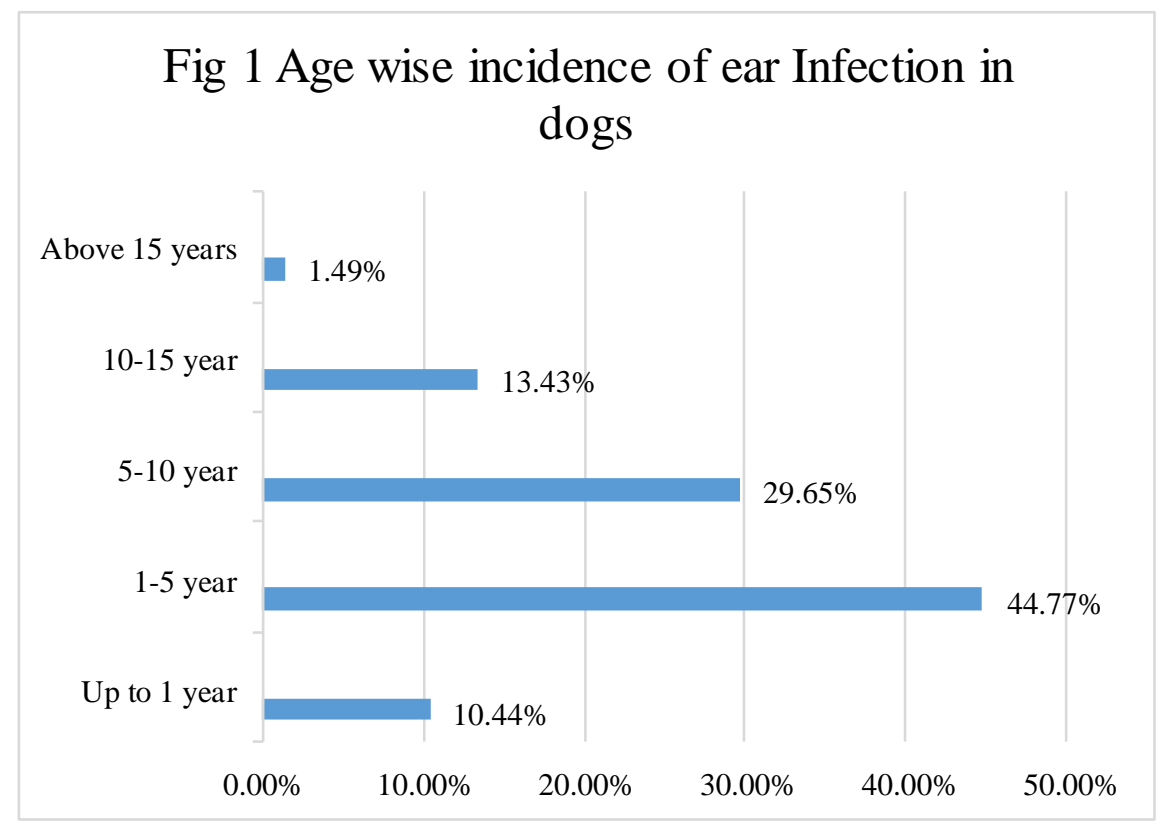

Fig.1 Age Wise incidence of ear Infection in dogs 


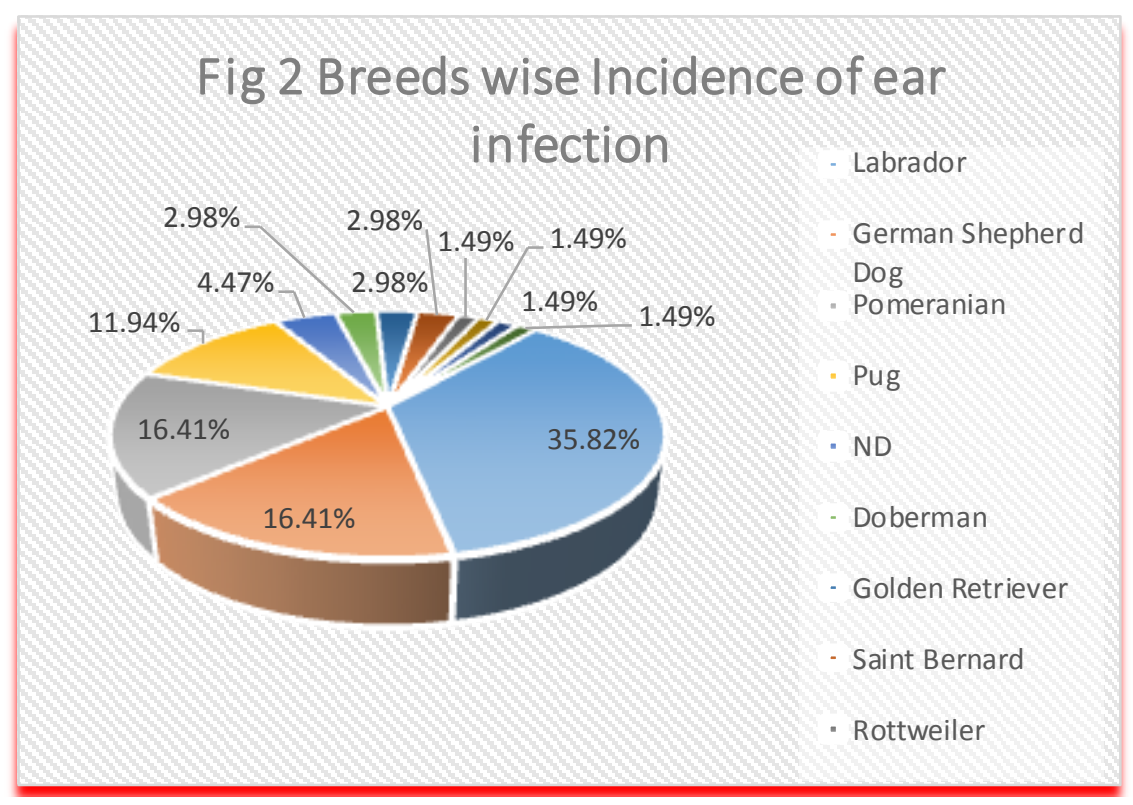

Fig.2 Breeds wise Incidence of ear infection

Otitis externa is very painful disease for dogs which leads to pain and discomfort to dogs. Thus, the preventive as well as therapeutic measures are necessary. The microbiological estimations are recommended for identification and antibiotic sensitivity for therapeutic management of otitis externa in dogs.

\section{References}

Bhojne, G.R., Sanghai, A.A., Dakshinkar, N.P. \& Thakur, K. (2015). Successful therapeutic management of geriatric vestibular syndrome in dogs. Indian Journal of Canine Practice, 7(2): 91-93.

Degi, J., Cristina, R.T. \&Stancu, A. (2010). Otitis Externa Caused By Bacteria of the Genus Pseudomonas in Dogs. LucrariŞtiintificeMedicinaVeterinara, XLIII (1): 143-147.

Manju, R., Roshan, K. \&Suhsovan, R. (2018). Prevalence of Canine Otitis Externa, Etiology and Clinical Practice in and around Durg District of Chhattisgarh State, India. International Journal of Current Microbiology and Applied Science, 7(3): 269-274.
Lakshmi, K. \&Tirumala Rao, D. S. (2013). Clinico-microbiological and therapeutic studies on canine otitis externa. International Journal ofPharma and Bio Science, 4(3): (B) 1209 - 1214.

Lodh, C, Chaudhary, S. \& Das, S. (2014). Therapeutic management of otitis externa in dogs. Indian Journal of Canine Practice, 6(1): 9-12.

Murugan, M. S., Parthiban, S., Malmarugan, S. \&Rajeshwar, J. J. (2016). Antibiogram and Therapeutic Management of Bacterial Otitis Externa - A Clinical Study of 81 Dogs. IntasPolivet, 17(II): 292-294.

Senthil Kumar, K., Selvaraj, P., Vairamuthu, S., Shammi, M. \&Kathiresan, D. (2010). Antibiogram patterns of microbes isolated from otitis externa of dogs. Tamilnadu Journal Veterinary and Animal Sciences, 6(3): 145-147.

Suneja, B. B., Amarpal, Aithal, H. P., Kinjavdekar, P., Pawde, A. M. \&Rathore, R. S. (2012). Microbial evaluation and management of otitis externa in dogs. Indian Journal of Canine Practice, 4(2): 149-151. 


\section{How to cite this article:}

Parmar.J. J., Neha Rao, Shah. A. I., Sadhu. D. B., Bhanderi. B. B. and Patel. D. M. 2020. Clinical Studies on Ear Infections, Microbiological Evaluation and Therapeutic Management in Canines. Int.J.Curr.Microbiol.App.Sci. 9(01): 1496-1501.

doi: https://doi.org/10.20546/ijcmas.2020.901.167 